\title{
Web-based material requisition system in the supply chain of construction businesses
}

\author{
Afolabi Olushola Adedeji ${ }^{1}$, Abraham Yewande S. ${ }^{2}$, Awosika Oluwafikunmi ${ }^{3}$ \\ ${ }^{1,3}$ Department of Building Technology, Covenant University, Nigeria \\ ${ }^{2}$ Rochester Institute of Technology, New York, USA
}

\begin{tabular}{l} 
Article Info \\
\hline Article history: \\
Received Jul 10, 2019 \\
Revised Aug 31, 2020 \\
Accepted Nov 4, 2020 \\
\hline Keywords: \\
Automation \\
Construction industry \\
Construction materials \\
Material requisition \\
Supply chain
\end{tabular}

Supply chain

\begin{abstract}
In the construction project delivery process, the supply chain of construction businesses can only be efficient and effective based on the prompt availability of building materials. Whereas, the process of requisition for the materials on the construction site, if not handled appropriately, can adversely affect construction performance. Therefore, the study was aimed at developing a web-based material requisition system (W-BMRS) that will make the supply chain on construction sites seamless and more effective. A use case and an activity block diagram provided an understanding of the users and functionalities of the material requisition platform. In addition, using a different user interface and a database system including a programming language to connect them, the study developed a web-based material requisition system for construction firms using the model view controller (MVC) model. The MVC model comprised of using MySQL, HTML, and PHP. The W-BMRS was tested by sending materials requisition through the supply chain of a construction firm. The results were presented via screenshots of the web-based platform. In conclusion, any construction firm can register on the platform and make use of the web-based materials requisition system to maximize productivity and optimize the use of ICT in their materials' supply chain process.
\end{abstract}

This is an open access article under the CC BY-SA license.

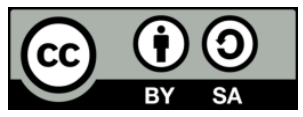

Corresponding Author:

Afolabi Adedeji

Department of Building Technology

Covenant University

Km 10, Idiroko road, Canaan Land, Ota, Ogun State, Nigeria

Email: adedeji.afolabi@covenantuniversity.edu.ng

\section{INTRODUCTION}

According to [1], the construction industry differs from other industries for three reasons, which are; the unique nature of the projects, site production, and temporary organization. Even with these peculiarities, efforts have been made to inculcate profitable practices of other industries in the construction industry in order to ensure the industry functions at higher efficiency and effectiveness. For instance, the construction industry has adopted information and communication technologies (ICT) for a wide variety of applications, including its use for the creation of smart and intelligent buildings. Instead of using conventional control means [2], noted that these smart technologies can help building owners and facility operators to monitor, control, supervise, and identify the potential for energy savings in buildings. In the last few decades, researchers and construction professionals adopted supply chain management (SCM) for construction processes. A supply chain can be defined as a specific series of steps or processes that are involved in the production and the distribution of materials, it describes the link between companies that transform basic materials and services to finished products for the client. Supply chain in construction therefore involves all 
construction companies, whether they are functioning as the designer, main contractor, surveyor, subcontractor, supplier, or the client. The supply chain of construction firms is divided into several segments which ensure the delivery of building materials to the construction site.

From ordering materials needed to contacting the supplier and final installation, each of these activities are critical and form an essential part of the construction process. One crucial aspect of the supply chain in the construction process is when materials are needed and a requisition order is to be instituted. A requisition is a listing of materials needed for a project which is filled out on the construction site and sent to the head office, before being sent to the supplier, it contains details of the materials needed and the dates on which they are needed. The requisition ultimately leads to the procurement phase and determines the supply of materials. Most times, on construction sites in Nigeria, a material requisition form is raised in order for the building materials to be supplied to the site. A materials requisition form in the construction industry is a source document used to request for materials used in the construction process. The materials requisition process can be divided into two parts, the first is a requisition made by the supervisor on site, this is sent to the head office of the construction company, the second part is sent from the head office to the supplier. The process of materials requisition stops when it reaches the supplier, after which the supply is made.

The problem with the material requisition process in Nigeria is that a large number of construction companies still carry out paper-based materials requisition, including the manual documentation of all the transactions carried out. This article aims to address this issue by introducing the use of ICT for material requisitions. Small construction companies, may not even have any mode of documentation, or have a specific process set aside for materials requisition, this means that there is no way of effectively following up requisitions. In Nigeria, building materials requisition are sometimes done via phone calls and word-ofmouth mechanisms which hampers the accountability, traceability, and sustainability of the process. There are lots of problems associated with not having proper record keeping and inventory of material supply chain in the management of construction sites [3,4]. Even for the paper-based methods, several changes have been attributed to its use for material recording. The use of a web-based system for materials requisition will ensure an easier and a more effective process, this way, the process can be followed and tracked from the requisition phase to the supply phase, with proper documentation for referencing. Integrating ICT in the materials requisition process is expected to reduce the possibility of fraud, and increase accountability on construction projects, therefore benefiting professionals involved in construction projects, and the construction industry at large. In this light, the study intends to develop a web-based material requisition system in a construction supply chain.

\section{REVIEW OF RELATED LITERATURE}

Many industries are becoming automated due to its efficiency and effectiveness in terms of speed, cost, quality, innovation, and customer satisfaction. Some sectors that have witnessed the use of automation include the power sector [5], education sector [6] and manufacturing sector [7]. The construction industry uses construction project management systems these systems can be developed in-house solely for company use [8]. For the construction industry, one of its activities that is in dire need for automation is the material management process. The material management process on construction sites can be divided into different phases. The study by [9] stated that material management is the business aspect of construction activities that deal with material planning, procurement, delivery, handling, storage, and releasing the material for use on the construction sites. For material management to be effective and efficient there is a need for a seamless supply chain. The use of ICT in the supply chain is not new and innovative technologies are being developed. Kasim [10] pointed out the use of bar coding and scanners, electronic data interchange (EDI), enterprise-wide information systems such as the use of enterprise resource planning (ERP) systems, radio frequency identification (RFID) and passive tags, e-commerce platforms and other web services. In the latter, previous studies have shown the use of web- based apps in the use of material supply in the procurement process of construction businesses [11]. The study utilized image processing sensors (IPS) and geographic information systems (GIS) to develop the web-based app to monitor material wastage in the supply chain process. Construction supply chain management (CSCM) was integrated with BIM and GIS [12]. Through this study, a decision support framework was developed to improve the efficiency of the supply chain in construction.

In Kulkarni [13] tracked different steps in the procurement process and created a decision making framework to assist in the determination of the order quantity and the reorder point. The need of a commercial information exchange in architecture, engineering and construction (AEC) supply chain firms was discussed [14]. The key factors that should be considered in these systems for implementation include technical, coordination, integration and organizational factors [14]. Koriom et al. [15] also considered commercial information exchange and e-trading solutions in construction. Examined studies that have looked into materials management and indicated that large construction contractors are applying materials 
management in their projects but there is a need for more studies considering small and medium contracting firms. Although, not specifically focused on the construction industry, Madhusudan and Rao [16] differentiated between an e-procurement system and a platform for making online purchases. They found that there was insufficient research in cloud-based e-procurement platform and mentioned the need to follow appropriate standards in the development of this system. Cardoso and Biazzin [17] considered the benefits of e-procurement to maintenance, repairs and operations suppliers. In Deraman et al. [18] developed an electronic purchasing (e-procurement) framework for construction also indicating that these systems have sometimes failed. According to [18], procurement policy, employee commitment, project milestones, change management, stakeholder involvement and project planning influence the decision to implement an eprocurement framework in the construction industry. Amade et al. [19] indicated that the most important factors for successful supply chain management was relationship among supply chain partners, supply chain financing and supply chain and continuous performance measurements. These studies have shown that a variety of factors should be included in the development of a SCM system.

In the study by [4], an IT framework was integrated with construction material planning and controlling system, whereby the proposed web-based system can prompt construction professionals on the shortfall of building materials on the construction site before a construction activity is carried out. However, the study did not link the construction material supplier into the loop in order to aid the supply of the needed building material. Whereas, this study aims to complete the loop from the point of need to the head office of the construction firm to the supplier and back to the construction site where the building material is needed. A close description of a web-based application in the supply chain of firms was developed in [20]. In [20], the web-based app was designed for a manufacturing business firm. In this web-based application, as described in [20], customers log on the web browser of the manufacturing firm (suppliers) and make a request for deliveries of their products. The web-based application in the supply chain then moves to select raw materials, produce and state the delivery time to the customer while also getting the customer feedback. It is worthy to note that the manufacturing sector differs from the construction industry in so many ways. Building materials in the construction industry are finished products making it easier to estimate, quantify and ready for delivery at any time. Unlike in [20], this study added the layer of the head office as an oversite and for approval of what is needed on each construction site before forwarding the request to the most qualified building materials' supplier. In simpler terms, some construction businesses use emails for their construction material requisition in the supply chain of their firms. The study by [21] noted that emails had become an integral part of most organizations by providing essential communication and collaboration channels. Lucas [22] argued that the important key in the use of emails is the informal knowledge flow among the firm's workers. However, the use of emails cuts across different activities on construction sites, thereby, encouraging the inability to filter correspondence on only building materials needed per site. This study suggested the need to have a concentrated platform specifically for building materials supply chain in construction businesses.

\section{RESEARCH METHODOLOGY}

The study designed a web-based system for material requisition to aid the supply chain management process. A model view controller (MVC) pattern of programming was used in developing the automated system as used in previous studies $[4,20,23,24]$. The automated system required a transactional database whereby the users can input data in the empty tables as the model. My structured query language (MySQL) was used as the real-time open source database system used to design the model. The study utilized a webbased interface as the view, which was designed using hypertext markup language (HTML) and the communication (controller) within the database was achieved using hypertext pre-processor (PHP) programming language. PHP is a highly used open-source technology, mostly suitable for web development and is usually embedded within HTML. PHP being an open-source software requires no licensing fees, hence it is cheaper to deploy than other server-side languages. In order to understand the web-pages to be designed and the functionalities required in the web-based material requisition, a use case diagram and an activity diagram were developed as shown in Figure 1 and Figure 2 respectively. The use case diagram and the activity block diagram were used to design the web-based system, which is accessible via the link http://bigtorch.com.ng/requisition/index.php.

Figure 1 shows the three primary users of the system in the supply chain process of material requisition. The process starts from the construction site where the materials are needed, to the head office where it is forwarded to the building materials' supplier. The activity block diagram for the material requisition platform shows how the different users will interact with the system. 


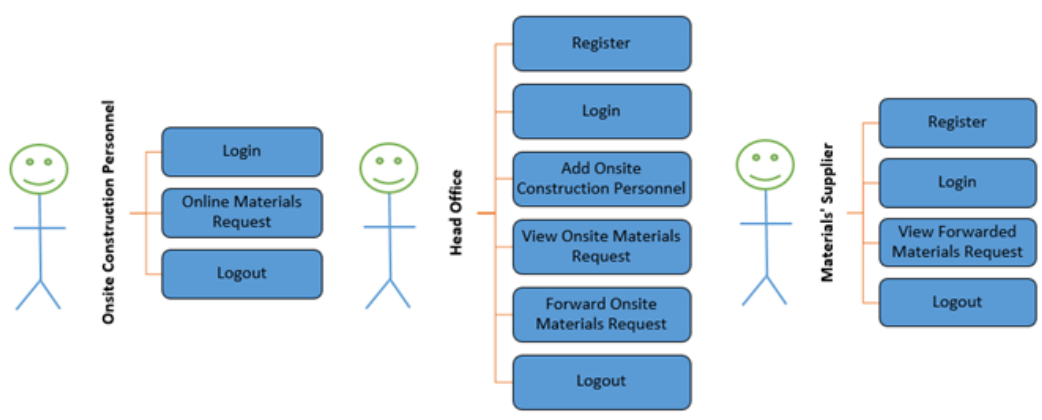

Figure 1. Use case diagram for the material requisition platform

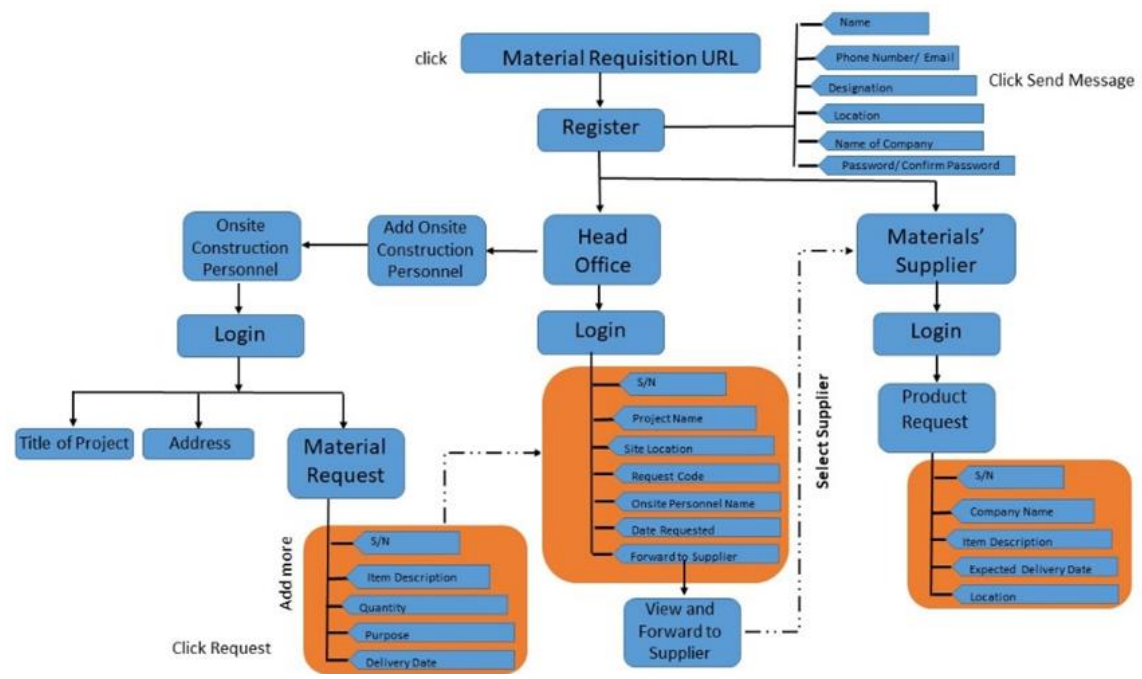

Figure 2. Activity block diagram for the material requisition platform

\section{SYSTEM IMPLEMENTATION}

In order to show the system implementation of the automated building material requisition platform for use by construction firms, the result was presented using screenshots. Figures 3 to 10 present the screen shots of the web-pages of the material requisition web-based system. The home page of the material requisition is presented in Figure 3. From the home page, users are able to click on their respective roles in the material requisition process.

Figure 4 presents the registration page for the head office and the suppliers. The head office and the suppliers need to register their companies on the web-based material requisition page in order to use the system. In this registration page, users enter their personal information and also provide an email address and password which will be used to login to the system.

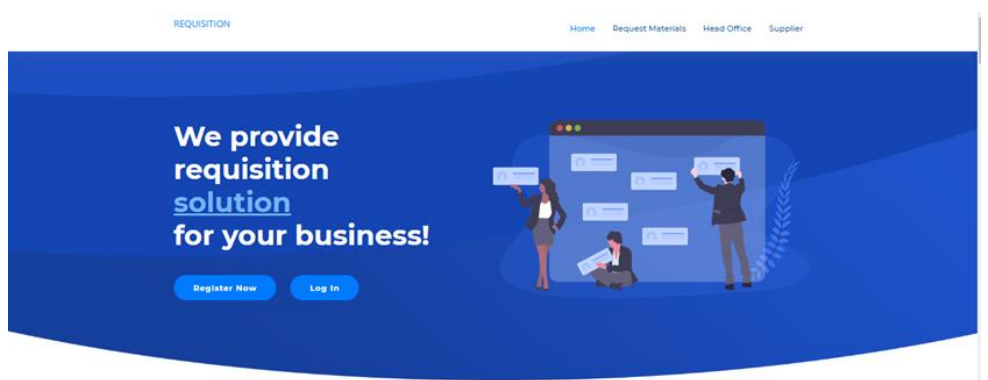

Figure 3. Home page of the web-based material requisition platform 


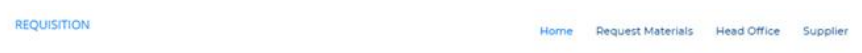

Register
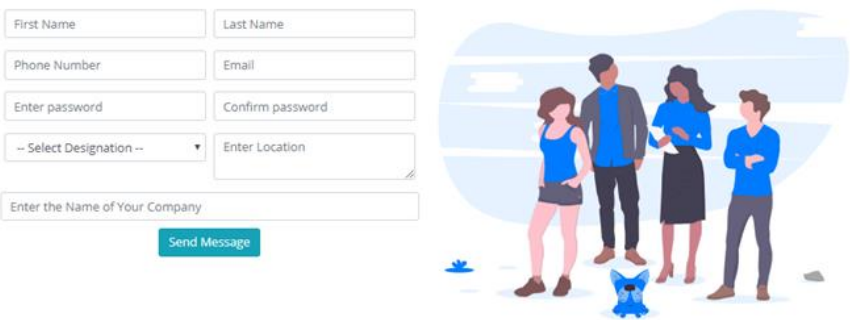

Figure 4. Registration as head office/supplier

For onsite construction personnel to access the material requisition web-based system, they need to be added to the system, as shown in Figure 5. Essentially, the email and password of the onsite construction personnel are created for the personnel by the head office in the system. Once all the users have their emails and password adequately registered on the platform, they can adequately login on the platform, as shown in Figure 6.

\section{Head Office - Dashboard}

Weicome, of AWOSIKA CONSTRUCTION

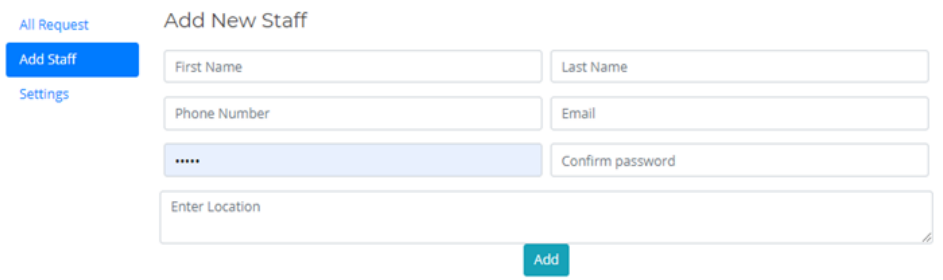

Figure 5. "Add onsite construction personnel" interface by head office

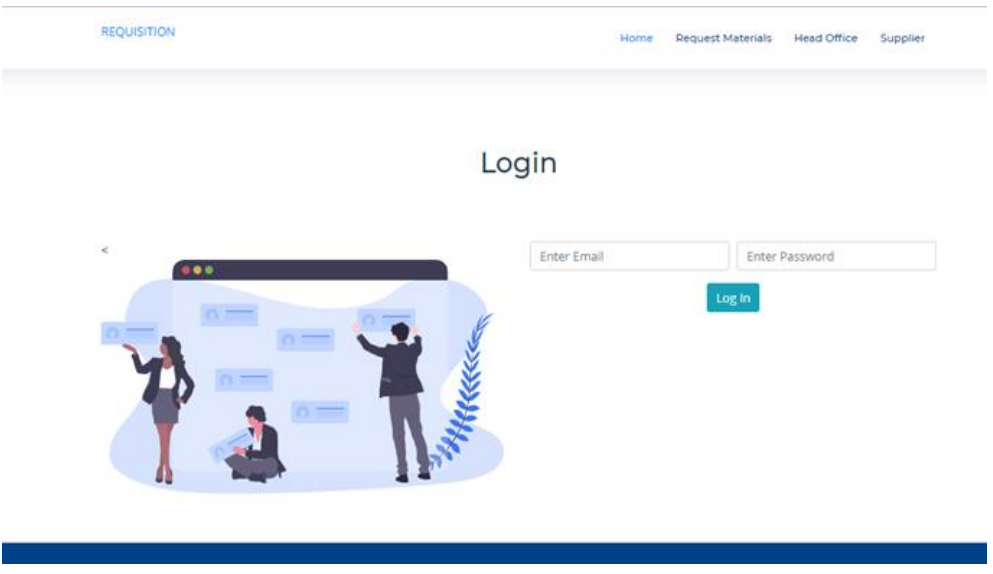

Figure 6. Login page in material requisition process 
In Figure 7, onsite construction personnel are able request the building materials as needed on the construction site. The name of the project, the location, the item needed and the expected delivery date is communicated to the head office via the material requisition platform. Figures 8 and 9 presents the view of the dashboard from the head office. The head office is able to view the material request needs for all the construction sites that the company operates and forward the request to suppliers that have registered with the company and registered on the platform. Figure 10 includes the dashboard for the supplier. The supplier can view the material request forwarded from the construction company and take action for the delivery of the material.

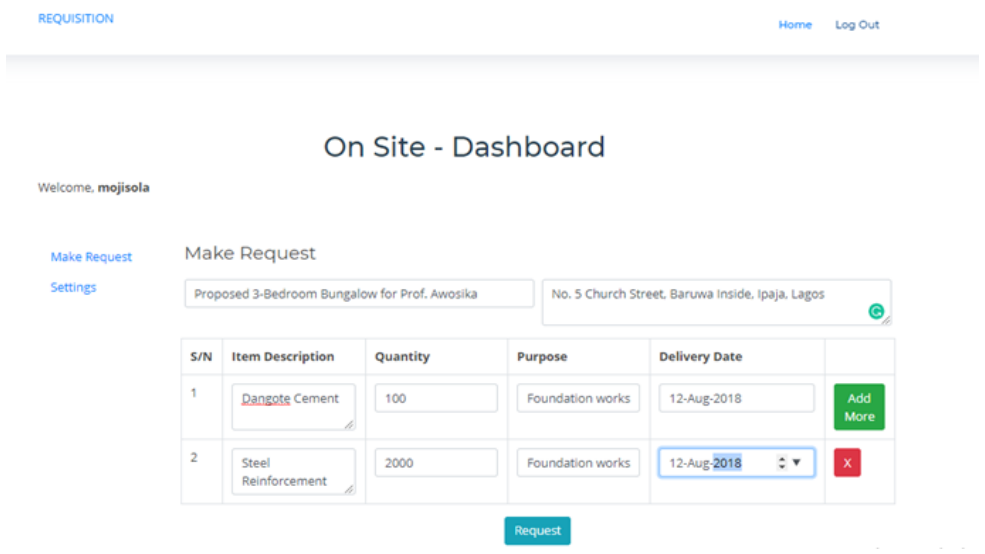

Figure 7. Request page from the construction site to the head office

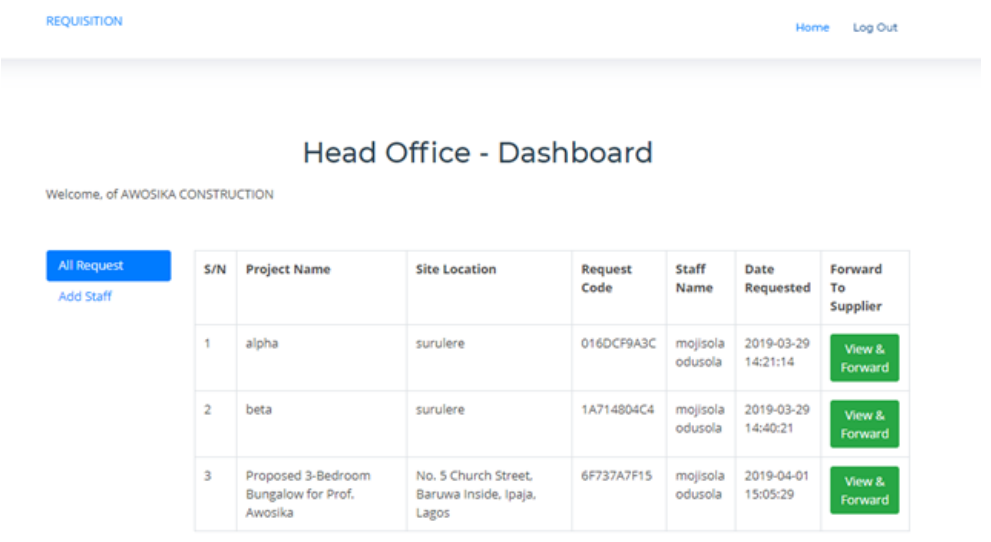

Figure 8. Dashboard of material request view at head office

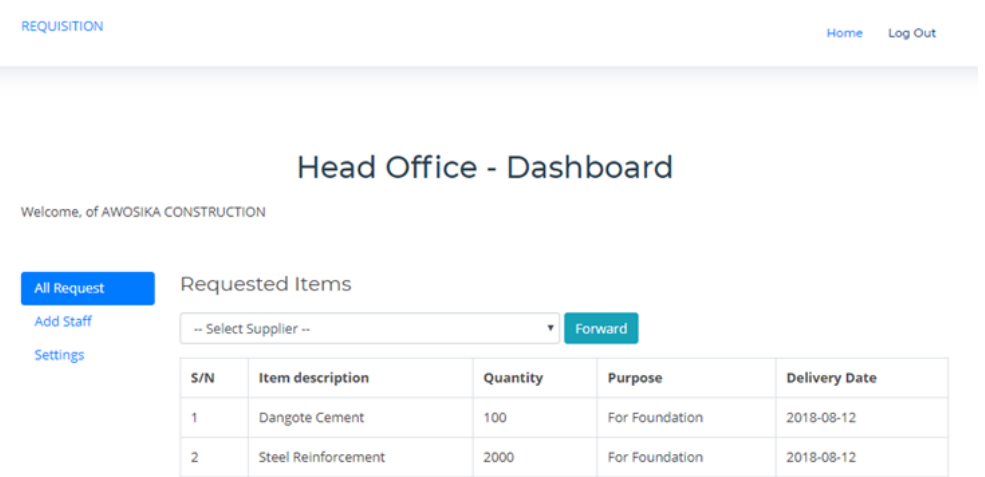

Figure 9. Forwarding of the material request from head office to the supplier 


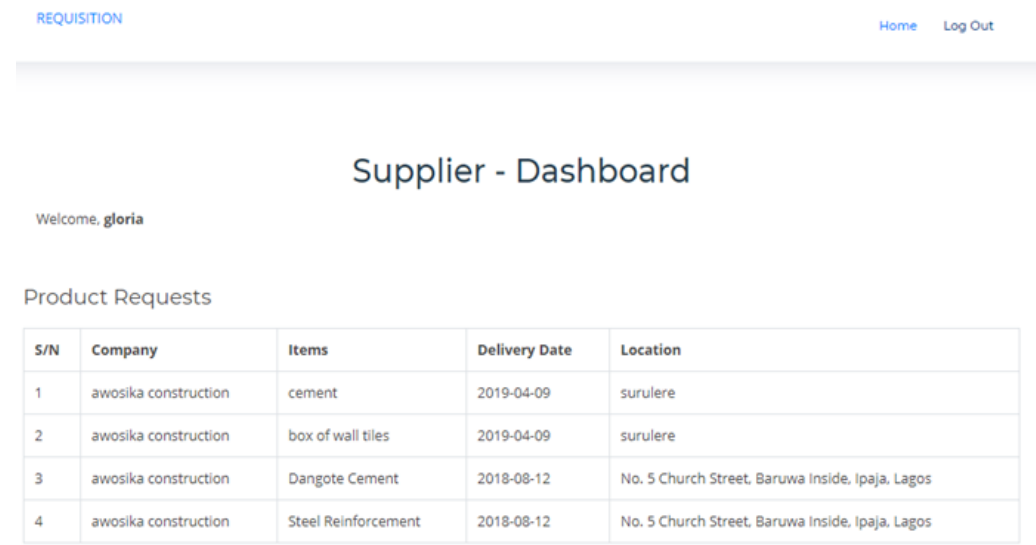

Figure 10. Materials’ supplier dashboard to view materials’ request

The web-based material requisition system has been tested using a construction firm's construction activities as the basis. These are the results presented in the screenshot in Figures 3 to 10. In comparison of this web-based system to others in previous studies in $[4,11,20,25,26]$, this study focused on the requisition of building materials on construction sites. The result achieved in this web-based material requisition system is that material requisition has been simplified and digitalized compared to the paper-based methods. Other studies had focused on the manufacturing sector and e-commerce platforms, but this study has specifically developed a web-based app for the construction industry. The material request moves from the construction site to the head office to the suppliers' platform. This study opines that when construction businesses adopt this web-based system for material requisition, they will be able to move from the traditional mode of paperbased requisition to a paperless requisition platform. In addition, this would aid proper record keeping and retrieval of information on material requisition. However, in using this web-based material requisition platform, all the users need a smartphone or laptop connected to the internet to access the services on the platform. Meaning that construction businesses need to invest in ICT infrastructure that support the web-based system and other suppliers that are not connected may be disenfranchised from the material requisition process.

\section{CONCLUSION}

The study aimed to develop a web-based material requisition system that will make the supply chain on construction sites seamless and more effective. Through the drafting of a use case diagram and an activity block diagram, the three (3) primary users of onsite construction personnel, head office, and materials' suppliers including functionalities of the material requisition platform were detailed. In addition, using a different user interface and a database system, including a programming language to connect them, the study developed an automated web-based material requisition system for construction firms using the MVC model. The MVC model comprised of using MySQL, HTML and PHP respectively in the design. The automated materials requisition system was tested by sending material requisition through the supply chain of a construction firm. The results of the web-based system were presented via screenshots of the material requisition platform. Different web-based interfaces such as the homepage, registration pages, onsite material requisition pages, forwarding of requisition to supplier pages were created. In conclusion, any construction firm can register on the platform and make use of the web-based material requisition system to maximize the productivity and optimize the use of ICT in their materials' supply chain process. Future work will include an evaluation of the system with construction professionals and suppliers to assess the effectiveness of this system and gather feedback on improvements. The study recommended the use of web-based systems in to ensure speed, accountability and sustainability of construction processes.

\section{ACKNOWLEDGEMENTS}

The authors appreciate the financial contribution of Covenant University Centre for Research, Innovation and Discovery towards the Open Access to the content of this article. 


\section{REFERENCES}

[1] M. B. Ali, Y. G. Yazed, A. B. Ayman, "Institutional smart buildings energy audit," International Journal of Electrical and Computer Engineering (IJECE), vol. 9, no. 2, pp. 783-788, 2019.

[2] V. C. Durai and K. Sentamilselvan, "A study on supply chain frame work in construction Industry," International Journal of Research, vol. 4, no. 8, pp. 16-26, 2016.

[3] A. Afolabi, et al., "Critical Success Factors (CSFs) for e-Procurement Adoption in the Nigerian Construction Industry," Buildings, vol. 9, no. 47, pp. 1-18, 2019.

[4] A. Afolabi, et al., "IT Management of Building Materials' Planning and Control processes using Web-Based Technologies," World Conference on Information Systems and Technologies WorldCIST 2017, vol. 570, pp. 12-19, 2017.

[5] A. Ademola, T. E. Somefun, A. F. Agbetuyi, A. Olufayo, "Web based fingerprint roll call attendance management system," International Journal of Electrical and Computer Engineering (IJECE), vol. 9, no. 5, pp. 4364-4371, 2019.

[6] Y. N. Doddaman, U. C. Kapale, "A transition from manual to intelligent automated power system operation-a indicative review," International Journal of Electrical and Computer Engineering (IJECE), vol. 9, no. 4, pp. 2274-2280, 2019.

[7] F. Fareeza, C. Rambabu, S. Krishnaveni, A. C. Kabiso, "Automation of DMPS Manufacturing by Using LabView and PLC," International Journal of Electrical and Computer Engineering (IJECE), vol. 8, no. 6, pp. 5484-5494, 2018.

[8] P. Nitithamyong and M. Skibniewski, "Web-based construction project management systems: how to make them successful?," Automation in Construction, vol. 13, no. 4, pp. 491-506, 2004.

[9] E. E. Ogbadu, "Profitability through effective management of materials," Journal of economics and International Finance, vol. 1, no. 4, pp. 99-105, 2009.

[10] N. Kasim, "Improving materials management practices in construction projects," International Symposium in Developing Economies: Commonalities among Diversities, pp. 356-369, 2011.

[11] A. Ahad, Z. R. Khan, S. Srivastava, "Application of IT in Supply of Construction Material Procurement," International Journal for Science and Advance Research in Technology, vol. 3, no. 7, pp. 638-642, 2017.

[12] Y. Deng, V. Gan, M. Das, J. Cheng and C. Anumba, "Integrating 4D BIM and GIS for Construction Supply Chain Management," Journal of Construction Engineering and Management, vol. 145, no. 4, p. 04019016, 2019.

[13] A. Kulkarni and S. Halder, "A simulation-based decision-making framework for construction supply chain management (SCM)," Asian Journal of Civil Engineering, vol. 21, no. 2, pp. 229-241, 2019.

[14] M. Pala, F. Edum-Fotwe, K. Ruikar, C. Peters and N. Doughty, "Implementing commercial information exchange: a construction supply chain case study," Construction Management and Economics, vol. 34, no. 12, pp. 898-918, 2016.

[15] N. Koriom, J. Brahim, I. Zakaria, A. Kaish and M. Mohsen, "The State of the Art of Materials Management Research in the Construction Industry," MATEC Web of Conferences, vol. 266, p. 05013, 2019, pp. 1-6.

[16] N. Madhusudan and L. Rao, "Insights on Extent of Effectiveness, Trend, and Gap in Existing Frameworks for eProcurement System," International Journal of Electrical and Computer Engineering (IJECE), vol. 6, no. 2, pp. 751-758, 2016.

[17] A. Cardoso and C. Biazzin, "What is the value of e-procurement for suppliers The drivers, barriers and opportunities for engaging MRO suppliers," International Journal of Procurement Management, vol. 13, no. 2, pp. 278-298, 2020.

[18] R. Deraman, C. Wang, J. Yap, H. Li and F. Mohd-Rahim, "Developing Internet Online Procurement Frameworks for Construction Firms," Future Internet, vol. 11, no. 6, p. 136, 2019.

[19] B. Amade, E. O. P. Akpan, U. F. Amaeshi, K. A. Okorocha and A. C., Ogbonna, "Delineating supply chain management (SCM) features in construction project delivery: The Nigerian case," International Journal of Construction Supply Chain Management, vol. 7, no. 1, pp. 1-19, 2017.

[20] K. C. Kodali, "Development of Web Based Application for Supply Chain Management," Culminating Projects in Mechanical and Manufacturing Engineering, vol. 60, pp. 1-56, 2016.

[21] D. Derks and A. B. Bakker, "The Impact of E-mail Communication on Organizational Life," Cyberpsychology: Journal of Psychosocial Research on Cyberspace, vol. 4, no. 1, pp. 1-6, 2010.

[22] W. Lucas, "Effects of E-Mail on the Organization," European Management Journal, vol. 16, no. 1, pp. 18-30, 1998.

[23] A. Afolabi, et al., "Construction Professionals' Perception of a Web-Based Recruiting System for Skilled Labour," Journal of Theoretical and Applied Information Technology, vol. 96, no. 10, pp. 2885-2899, 2018.

[24] A. Afolabi, et al., "Development of a Web-Based Tendering Protocol for Procurement of Construction Works in a Tertiary Institution," Journal of Theoretical and Applied Information Technology, vol. 95, no. 8, pp. 1595-1606, 2017.

[25] B. H. Solanke and J. A. Fapohunda, "Impacts of E-Commerce on Construction Materials Procurement for Sustainable Construction," World Congress on Sustainable Technologies, 2015, pp. 65-70.

[26] B. Omar and T. Ballal, "Intelligent wireless web services: context-aware computing in construction-logistics supply chain," Journal of Information Technology in Construction, vol. 14, pp. 289-308, 2009. 